\title{
Author Correction: The role of mPFC and MTL neurons in human choice under goal-conflict
}

Tomer Gazit, Tal Gonen, Guy Gurevitch (D), Noa Cohen, Ido Strauss, Yoav Zeevi, Hagar Yamin, Firas Fahoum (D), Talma Hendler (1D) \& Itzhak Fried

Correction to: Nature Communications https://doi.org/10.1038/s41467-020-16908-z, published online 24 June 2020.

The original version of this Article contained an error in the Acknowledgements section. This section was missing the sentence 'Special thanks to Dr. Eran Eldar (Hebrew University of Jerusalem) for the inspiration and access to early versions of the PRIMO game.' The error has now been corrected in both the PDF and HTML versions of the Article.

Published online: 10 August 2020

(c) Open Access This article is licensed under a Creative Commons Attribution 4.0 International License, which permits use, sharing, adaptation, distribution and reproduction in any medium or format, as long as you give appropriate credit to the original author(s) and the source, provide a link to the Creative Commons license, and indicate if changes were made. The images or other third party material in this article are included in the article's Creative Commons license, unless indicated otherwise in a credit line to the material. If material is not included in the article's Creative Commons license and your intended use is not permitted by statutory regulation or exceeds the permitted use, you will need to obtain permission directly from the copyright holder. To view a copy of this license, visit http://creativecommons.org/licenses/by/4.0/.

(C) The Author(s) 2020 